\title{
UNDERSTANDING THE DIFFUSION OF SMALL WIND TURBINES IN KENYA
}

\section{A technological innovation systems approach}

\author{
Faith H. Wandera
}

\begin{abstract}
Kenya has a long history of wind energy development, but the potential for stand-alone small scale wind for electricity generation remains relatively unexploited to date. This prompts the questions of whether a technological innovation system for small wind exists, how well the system functions are fulfilled, and how the diffusion of technology is either blocked or induced. Using an innovation systems perspective and a technological innovation systems approach, data was sourced from literature, small wind business firms, and other actors. A technological innovation system for small wind is established to exist as most of the key actors are present; however, the system functions are weakly fulfilled. Key blocking mechanisms are in the functions of market formation, knowledge development, resources mobilisation, and guidance of the search. The function of creation of legitimacy has a weak inducing effect. The need for government support to conduct site-specific assessments, set specific development goals, and enhance financial support for small wind development is implied.
\end{abstract}

\section{Introduction}

Kenya is estimated to have a decentralised market of about 6.7 million households (MOEP, 2016), and a possible paradigm shift to decentralised electricity generation exists (Pueyo, 2015). Small wind turbines (SWT) less than $100 \mathrm{~kW}$ (Pitteloud and Gsänger, 2017) have the potential to contribute to a decentralised, small-scale pathway of electricity supply to enhance access to clean energy sources, particularly in remote areas where extension of the grid is not financially and economically viable compared to a large-scale pathway that relies on grid supplied electricity (Hansen et al., 2018). With correct placement, SWTs offer 
potential for ensuring a pollution-free environment (Berges, 2007) in remote areas over a shorter gestation period (Ashok, 2007) and could guarantee the creation of more jobs per dollar invested per kilowatt-hour generated than fossil generation through direct job creation over their lifetime (Lewis and Wiser, 2005).

But the decision to tap into SWT requires a stronger evidence base. A discussion with a renewable energy consultant in Kenya indicated the price of SWT to be 1.5 to 2 times that of solar photovoltaic (PV). For every watt of wind installed one needs 3-5 \$ compared to 2-2.5\$ for solar for installations less than $100 \mathrm{~kW}$. In decentralised electrification, PV neither competes nor substitutes SWT. There are over 200,000 solar PV systems installed in Kenya, and annual sales are estimated at 20,000 systems (MOEP, 2016) with 30-40 distributor firms and 600 trained technicians. By comparison, the installed number of SWT systems in Kenya is estimated to be 500 , mostly of $1-10 \mathrm{~kW}$ serving the communications industry, with about 20 SWT distributor firms and limited availability of trained technicians. The trend in the solar PV industry has been made possible by the emergence of innovative business models and the rapid decline in global prices of solar PV, thus making it a dominant technology in decentralised electrification.

While many studies have been conducted on the diffusion of SWT in developed countries, relatively fewer studies on this topic have been conducted in developing countries, especially in East Africa. This chapter presents the Technological Innovation Systems (TIS) approach to studying the diffusion of SWT in Kenya and hence provides evidence that supports the contribution of SWT to electrifying communities who lack access to grid electricity. To the author's knowledge, this is the first time small wind turbine diffusion has been considered from an innovation systems perspective. Use of the TIS framework is based on its ability to enable the understanding of the adoption and impact of technologies, as well as to reflect the socio-economic context present in developing countries (Edsand, 2016). These are key areas of interest for policy makers in making choices on the types of technology to promote. The chapter contributes methodological insights on how to adjust indicators of the TIS framework when applied in a developing country context.

The research findings presented in this chapter argue for the improvement of energy policy frameworks by increasing attention to the role of SWT in decentralised energy access in Kenya, particularly the setting of long-term goals for renewable energy (RE) development that incorporate SWT, allocation of adequate resources, local manufacturing and market development, conducting sitespecific assessments in potential areas, and support for the integration of SWT in hybrid mini-grids (Nema, Nema, and Rangnekar, 2008). The study applied a mix of methods to answer the following research questions: does a TIS for diffusing SWT exist in Kenya? If it does, how well does it function? What are the main inducing and blocking mechanisms within the TIS?

The chapter is structured as follows: first insights on studying technology diffusion in developing countries using the technological innovation systems framework are presented. Then the methodology is described covering the scope 
and boundaries of the research, details of indicators, and method employed in data collection. An empirical analysis of the SWT TIS in Kenya covering the description of actors, assessment of the performance of the system functions, and a highlight of the blocking and inducing mechanisms is presented followed by an evaluation of the performance of the system functions. Lastly, the chapter concludes on the study findings, key policy issues, usefulness of the TIS framework, and the prospects for technology diffusion.

\section{Studying technology diffusion in developing countries using the technological innovation systems framework}

The National, Regional, and Sectoral/Technological Innovation Systems concepts focus on explaining the nature and rate of technological change (Hekkert et al., 2011). The emergence of the TIS framework alongside other innovation system approaches points towards the rise in systemic approaches to the study of technology development. The systemic approach contrasts with the 'linear model of innovation', where knowledge flows are modelled simply as research that leads to product or technology development which enter the market (OECD, 2008) without attention to feedback mechanisms.

The TIS framework focuses on technology specific factors while taking into account interactions with other systems at sectoral and national levels, thus providing a methodological tool for addressing complex dynamics through the aggregation of influences. It takes the technology as the focal point around which to consider system interactions and the influence of internal and external pushes and pulls rather than a sectoral or national focus. The benefits of the TIS framework are the capability to analyse the complex nature of the emergence and growth of new industries as well as the facilitating factors, termed 'inducing mechanisms', and obstacles, termed 'blocking mechanisms' (Jensen et al., 2007). Inducing or blocking mechanisms are likely to vary with the specific circumstances and context being examined, thereby enabling the translation of obstacles to intervention measures in the form of systemic instruments and policy mixes and enhancement of the inducing mechanisms for better performance of the system (Bergek et al., 2015).

Many studies have applied the TIS framework to emerging clean technology sectors, which signifies its importance as a major building block of sustainability transitions research (Bergek et al., 2015). The application of the TIS framework in the understanding of diffusion processes in developing economies is still a subject for debate. While some argue that the TIS framework was initially designed to understand diffusion of innovations in developed countries, which makes the possibilities for its application to developing or emerging economies limited (Kebede and Mitsufuji, 2016), others support its application. This study draws inspiration from various studies that have used the TIS framework to analyse RE sectors in developing country contexts (van Alphen, Hekkert, and van Sark, 2008; Furtado and Perrot, 2015; Kebede and Mitsufuji, 2016; Kingiri and Fu, 
2019; Tigabu, Berkhout, and Beukering, 2014). Based on the extensive review of literature conducted, until now no study has utilised a TIS framework to study small wind turbines in sub-Saharan Africa.

\section{A technological innovation systems perspective of the system components}

The structural components of a TIS include the actors responsible for generation of knowledge (e.g., knowledge institutes, educational organisations, industry, market actors, government agencies, and supportive organisations); formal or informal institutions for formulating the rules of the game that shape human interaction (e.g., hard legislation including standards and intellectual property rights and soft legislation including ethics, norms, and behaviour); and networks and technological factors which are interactions regulated by for example institutional practices, education, and supply and demand (Hekkert et al., 2011). The focus is specifically on the role of actors, institutions, and networks in the diffusion of SWT.

Actors function in networks which may be either localised or globalised in nature. Interactions between individuals, groups, and organisations are regulated by institutions (Edquist, 2001) which are relevant for reducing uncertainty by providing information, managing conflicts and cooperation, and providing incentives for innovation. Institutions relevant in technology diffusion include publicly funded research and development (R\&D), regulations and policy instruments, and technical norms such as the materials and equipment (Markard and Truffer, 2008). Literature suggests that learning networks are a crucial determinant in a firm's ability to obtain success with a new technology (Lewis, 2007). Networks also facilitate changes in the social dimension such as the user practices, regulation (Hekkert et al., 2007), and resource market activation campaigns and partnerships as a potential means of creating the demand, pressure, policy, regulatory foundation and interaction with international markets (Bruton, Ahlstrom, and Obloj, 2008) that is necessary for sustaining distributed energy markets. Because institutions and networks of agents take part in the generation, diffusion, and utilisation of specific technologies, the focus of analysis is technological innovation systems (Hekkert and Negro, 2009).

Such analysis has been used to identify systemic problems that hamper the development and diffusion of technological innovations (Negro, Alkemade, and Hekkert, 2012). The systemic problems relate to market structure, infrastructure, institutions, interactions, and capabilities. Measuring how innovation systems function is considered as a big breakthrough in innovation systems research (Hekkert et al., 2011). It entails the use of specific diagnostic questions in assessing the performance of specific functions. Comparing the main channels for knowledge flows, identification of bottlenecks, and suggestion of policies and approaches helps improve fluidity (Hekkert et al., 2011). Institutional mapping focuses on formal rather than informal institutions because of the difficulties 
associated with systematic mapping of the latter despite their relevance in influencing the performance of systems. By tracing the links and relationships among industry, academia, government, private sector, non-governmental development actors, and other agencies, systemic failures that impede a transition towards renewables and obstruct the formation of powerful functions could be identified (al-Saleh, 2011). These could be in the form of insufficient linkages between the actors, lack of entrepreneurial spirit, weak science and technology infrastructure and capabilities, under-developed educational and research capabilities, technical hurdles associated with renewables (mainly intermittency and high costs), lack of democracy and transparency in terms of policy making, and weak advocacy coalitions (al-Saleh, 2011). A combination of a few or all these could result in poor performance of the system functions, thus affecting the diffusion of RE technologies.

New technologies usually require long periods of nurturing before they achieve price parity that attracts larger segments in the market (Jacobsson and Johnson, 2000). In a TIS, the innovation activity of each actor contributes to one or several functions of the TIS, thus determining the performance of the system (Markard and Truffer, 2008), and hence how well diffusion takes place. Market development may depend on the emergence of new and innovative alliances of actors to meet the service needs of the excluded poor while delivering profits for business firms (Kuratko, 2010). Low diffusion could result from poor articulation of demand occasioned by inadequate or incorrect information. Demand could be stimulated through creation of awareness on the functioning thereby stimulating the uptake of technology. Technology diffusion occurs through the interactions of actors within networks. The diffusion of technologies undergoes five distinct phases, namely pre-development, development, take-off, acceleration, and stabilisation.

The formation of markets is not spontaneous, and articulation of demand particularly in the pre-development and development phases depends on the potential of the innovation system to create markets (Jacobsson and Johnson, 2000). New technologies are likely to suffer competition from incumbent substitutes offering better returns, thus causing the new product to be associated with a high price and low utility value. In the absence of nurturing, it may be difficult for the new technology to overcome these disadvantages. Changing the technological base of a firm happens slowly, implying that their search is often restricted to local developments, thus rendering them ignorant of available opportunities for diffusing technology (Jacobsson and Johnson, 2000).

\section{Diffusion of small wind turbines}

Wind technology has existed in Kenya since 1986 for mechanical water pumping. Later, large-scale systems were developed for electricity generation, for example the Ngong Wind (25 MW) power project and the Lake Turkana Wind (310 MW) power project (Kenya Miniwind, 2018). Further, SWT have been 
TABLE 5.1 Diffusion of SWT in selected countries, no. of systems installed and total capacity $(\mathrm{kW})$

\begin{tabular}{lllll}
\hline Country & $\begin{array}{l}\text { No. of systems } \\
\text { installed }\end{array}$ & Date of Data & Total capacity $(k W)$ & Date of data \\
\hline China & 732,000 & 2015 & 415,000 & 2015 \\
USA & 160,995 & 2015 & 230,400 & 2015 \\
United Kingdom & 28,917 & 2015 & 146,192 & 2015 \\
Italy & 1,725 & 2015 & 59,833 & 2015 \\
Germany & 17,000 & 2015 & 26,000 & 2015 \\
Japan & 10,500 & 2011 & 5,258 & 2011 \\
South Korea & 1,900 & 2011 & 1,200 & 2011 \\
Denmark & 1,036 & 2015 & 8,600 & 2015 \\
Kenya & 500 & 2018 & Not available & 2018 \\
Morocco & 200 & 2012 & 700 & 2012 \\
India & Not available & 2017 & 2400 & 2012 \\
\hline
\end{tabular}

Source: Pitteloud and Gsänger, 2017 except for Denmark installed systems data which is based on http://www.windworks.org/cms/index.php?id=64\&tx_ttnews\%5Btt_news\%5D=3772\&cHash $=\mathrm{a} 66 \mathrm{~b} 51 \mathrm{c} 490535 \mathrm{bfe} 2 \mathrm{~d} 4 \mathrm{f} 98 \mathrm{c} 7 \mathrm{dffb} 3 \mathrm{c} 14$ and Kenya data which is sourced from Hansen et al. (2018).

documented to be viable for electrification in developing countries (Foster, 2011), but examples of these are limited in Kenya. A literature search did not identify examples of SWT diffusion in neighbouring regions, except Ethiopia where the industry is not well developed (Eales, 2014). Table 5.1 shows the diffusion of SWT in selected countries across the world. The upper capacity limit of small wind ranges between $15 \mathrm{~kW}$ and $100 \mathrm{~kW}$ for the five largest small wind countries (Pitteloud and Gsänger, 2017). The definition of SWT by IRENA (2015) is based on the International Electrical Commission (IEC) 61400-2 standard whose definition corresponds to $50 \mathrm{~kW}$. This study was based on the (Pitteloud and Gsänger, 2017) definition which gives the upper limit of SWT as $100 \mathrm{~kW}$.

The search by national governments for viable electrification solutions is often limited by the cumbersome nature of initiating interactions with actors who may not be within easy reach (Foster, 2011). Special measures may therefore be required to help promote technology diffusion, including diffusion of RE and SWT in particular. An in-depth understanding of the functioning of the TIS for SWT in Kenya is thus critical for defining policies and actions that may contribute to increased access to electricity services, particularly in wind resource rich areas where grid extension is not economically feasible. This section has discussed the structuring of the TIS, identification of systemic problems, the role of the various components, and technology diffusion with specific reference to SWT.

\section{Methodology}

The methodology is based on broader knowledge from a forthcoming PhD dissertation examining technology innovation systems, capabilities, barriers, and 
opportunities for diffusing SWT in Kenya, and a journal paper on 'The innovation system for diffusion of small wind in Kenya: strong, weak or absent? A technological innovation system analysis' (Wandera, 2020). The scope of this study was the SWT TIS in Kenya narrowed by excluding grid-connected systems larger than $100 \mathrm{~kW}$ and mechanical applications for water pumping. Hence the system boundary reference for the study was 'grid-connected or isolated SWT systems less than $100 \mathrm{~kW}$ ' for energy service provision to communities lacking access to the grid because of geographical location or economic and feasibility reasons.

The seven functions of the TIS framework by Hekkert et al. (2007) were used as the organising principle to identify the blocking and inducing mechanisms and assess the performance of the SWT TIS in Kenya. Choice of the Hekkert et al. (2007) framework over the Edsand (2017) framework was informed by the technology being analysed, the concepts guiding the study, and the indicators adopted. The indicators of the TIS framework were adjusted as indicated in Table 5.2 because the TIS was originally intended for application in developed rather than developing countries. The two have different contexts of technology development which are likely to vary with respect to structure, actors, and processes. The adjustment may therefore imply that the indicators used in this study are only applicable to developing country contexts similar to Kenya.

The adjustments included: for Function 1 (entrepreneurial activities), new entrants and number of experiments were not considered, as only very few firms focus on SWT (entrepreneurial focus in Kenya is on solar PV). The number of experiments on SWT is low and would present data collection constraints. For Function 2 (knowledge development), patents were not considered, as literature review established that most of the business firms were engaged in importation rather than manufacturing and even less so in R\&D. Other aspects of knowledge development elaborated in Table 5.2 were considered. Function 3 (knowledge diffusion through networks) focused on the nature and frequency of interactions rather than the number, owing to the possible inaccuracies posed by the difficulty of accurately recalling figures particularly since record keeping on interactions is not the norm. For Function 5 (market formation), the suggested indicator 'niche markets introduced' was not considered, as niches for SWT are not well defined and would present difficulties in data collection. Emphasis was on the creation of an enabling environment, a function performed by governments. Functions 4, 6, and 7 were utilised without change.

Multiple data collection methods were applied, including email questionnaires, face-to-face interviews, and literature search of refereed journals and published reports using the following search terms: technology diffusion; small wind turbines; technology innovation systems; and decentralised electrification. The different types of data were triangulated so as to strengthen the validity of the findings (Aguinis et al., 2011). Both qualitative and quantitative data were collected from business firms and actors in the SWT innovation system, including government agencies, networks, consultants, and development partners. Business firms were identified through an 
TABLE 5.2 Recommended versus applied indicators (sourced from various literature) for analysing the performance of a technological innovation system

\begin{tabular}{ll}
\hline Function & Recommended indicators Adjusted indicators applied in this study \\
& in TIS literature (Hekkert \\
et al., 2011)
\end{tabular}
1 Entrepreneurial New entrants; activities the number of diversification activities of incumbent actors; and the number of experiments with the new technology
2 Knowledge Development
R\&D projects; patents; and investments in $\mathrm{R} \& \mathrm{D}$

3 Knowledge diffusion through networks

4 Guidance of the Specific targets set by search
Number of workshops and conferences devoted to a specific technology topic; the network size; and intensity over time
Activities in SWT business firms; number of firms in the TIS; sales of SWT; local manufacturing; use of external expertise; access to financing

Availability of up to date knowledge; intensity of higher level education for skills development; adequacy of the training curriculum; evidence base (learning by doing/using) (commercialisation); level of experimentation; venturing into wind hotspots; reverse engineering; conducting feasibility assessments; linkages with public research organisations; local worker skills development

Availability of networks; focus of networks; networking capabilities with local and foreign actors; interactions and knowledge sharing; knowledge of the Kenyan market; integration of new knowledge; awareness on benefits of SWT; public awareness of technology; no. of systems and demonstrations installed

Government long-term goals for SWT; industry long-term goals for SWT; incorporation of SWT in ongoing projects; utilisation of lessons from successful and unsuccessful projects; coverage of positive SWT developments in professional journals 
TABLE 5.2 (Continued)

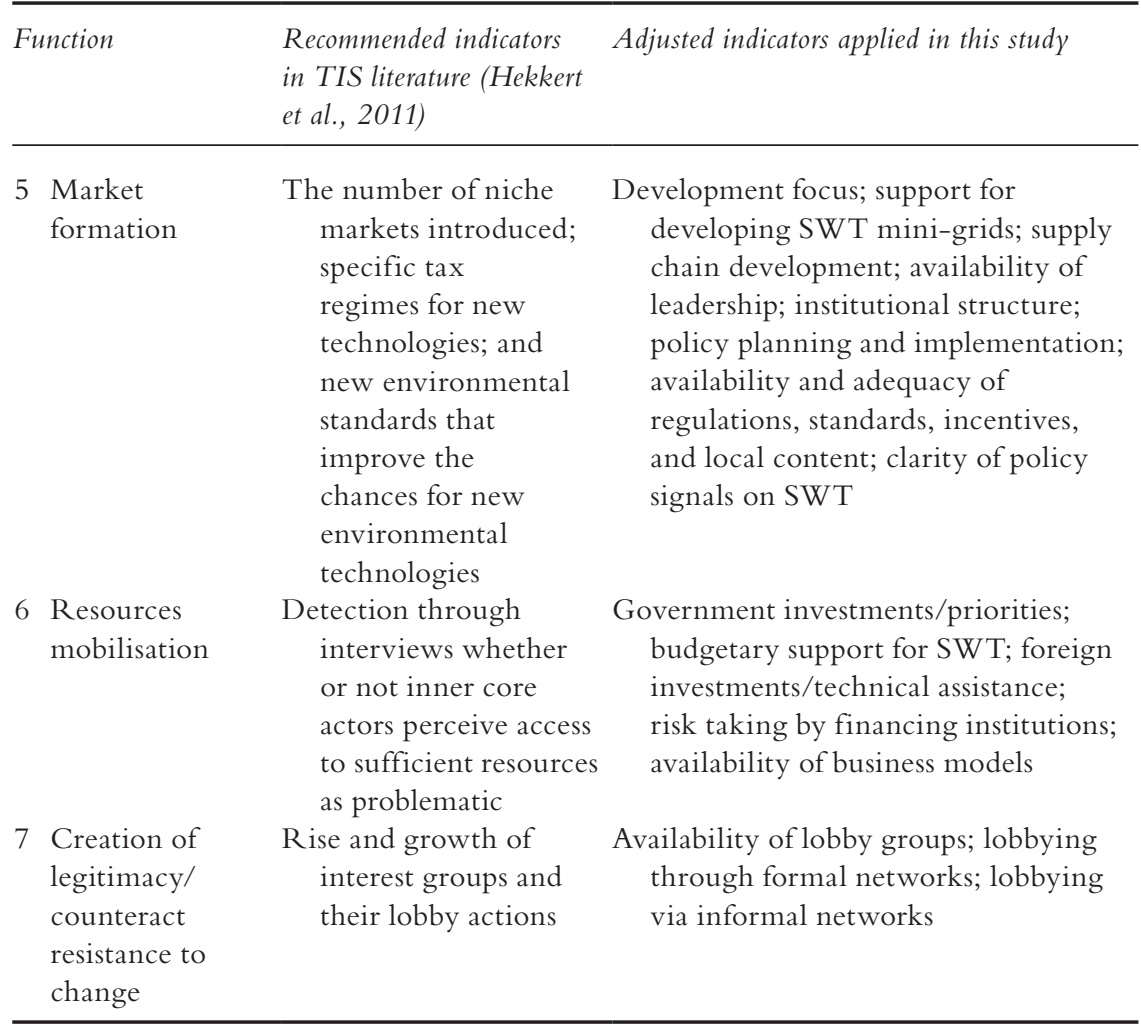

Source: Based on Hekkert et al. (2011).

internet search of websites of firms engaged in the manufacture, importation, and sale of SWT technology in Kenya. Additional actors were identified through literature and snowballing during interviews. Altogether, 14 representatives of business firms and 12 other actors were interviewed in Kenya in late 2017 and early 2018 bringing the total number of interviewed to 26 , in addition to 11 emailed questionnaires. Two of the business firms were local manufacturers of SWT. Quantitative data was analysed using descriptive statistics and interpretations made from tables and histograms generated. Data from interviews, case studies and published literature was analysed by thematic coding, identification of common themes, and presentation in narrative form. Evaluation of the fulfilment of the TIS functions was done by assigning values $(-1$ representing a strong blocking effect and +1 representing a strong inducing effect).

\section{SWT TIS Kenya: an empirical analysis}

The Hekkert et al. (2011) framework recommends mapping out the structure of the SWT technological innovation system. It entails identifying the actors and 


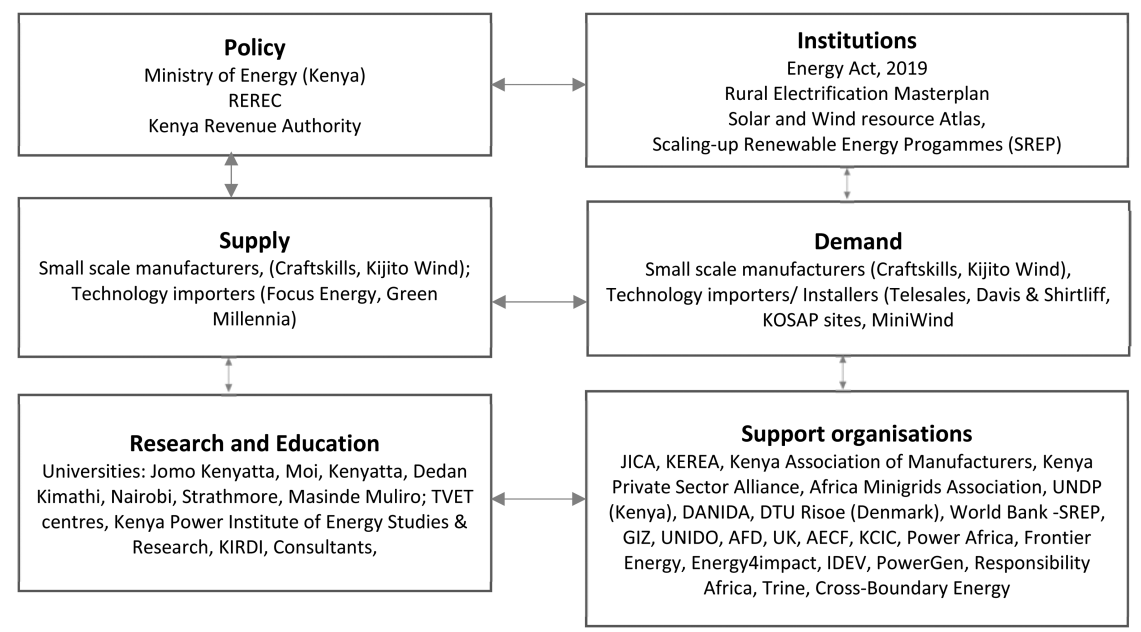

FIGURE 5.1 Actors in the small wind turbine Technological Innovation System in Kenya. Source: author; utilising actor groupings in Hekkert et al. (2011).

the relations between them and hence the structure within which all the identified actors operate. Figure 5.1 is a mapping of the actors in the SWT innovation system in Kenya.

\section{Analysis of the performance of the SWT TIS functions}

The performance of the SWT TIS was analysed based on the seven system functions, namely: (1) entrepreneurial activities; (2) knowledge development; (3) knowledge diffusion through networks; (4) guidance of the search/articulation of demand; (5) market formation; (6) resources mobilisation; and (7) creation of legitimacy/counteract resistance to change and the interactions.

\section{Function 1: entrepreneurial activities}

Literature sources established the existence of approximately 20 companies offering imported SWT in Kenya, predominantly installers of solar PV systems who complement their energy product portfolio with SWT products on a demand basis (Kamp and Vanheule, 2015). The bias to solar PV is explained by the low prices and greater availability of business models (reported by five out of six business firms). Among these are two local manufacturers of SWT whose operations in Kenya date back to the 1980s. One of them specialises in water pumping, while the other focuses on electricity generation. By comparison, interview with the Kenya Renewable Energy Association (KEREA) indicated that there are more solar PV importers (about 30-40) supported by about 
300-400 distributors who target the rural areas of Kenya to grow their business. Most of the business firms are concentrated in the city of Nairobi which is relatively well served by the grid. Only one firm operates an outlet located in wind resource rich areas. These areas are difficult to access because of poor road infrastructure and insecurity (reported by five out of six business firms). Consequently, the solar PV products enjoy better market penetration compared to SWT whose sales by individual companies are in the range of one to five units over a four year period (reported by 13 out of 24 interview respondents). It is estimated that the installed number of systems is 500 in the whole country, mostly in the range of 1-10 kW (Hansen et al., 2018). Findings from literature, however, indicate SWT to be a better investment in the most appropriate sites when compared with solar PV on a technology versus technology basis (Fleck and Huot, 2009). Most project stakeholders including developers, promoters, and users indicate the lack of information to be a major obstacle (7 out of 11 interview respondents). The transfer of new knowledge from foreign firms with better experience in diffusing SWT is limited which therefore constrains the acquisition of technological innovations by firms (8 out of 11 interview respondents). Most firms were established to rely on advertising through their websites, an approach that limits public access to information and consequently contributes to the low awareness on SWT technology benefits (7 out of 11 respondents).

\section{Function 2: knowledge development}

The status of knowledge development and the technological base for SWT in Kenya is established from literature to be highly informal and comprises largely small-scale locally manufactured and imported systems (Hansen et al., 2018). The business firms indicated acquiring new knowledge from exhibitions and trade fairs despite the majority of these events focusing on solar PV which renders the acquisition of knowledge on SWT negligible. The training curriculum in tertiary agencies was indicated to be out of date with SWT developments in other parts of the world (8 out of 11 respondents), a factor that constrains the generation of new designs of SWT. Two prototypes developed at Jomo Kenyatta University of Agriculture and Technology in the 1990s are yet to be commercialised and only one local company is in commercial production. The focus of tertiary learning was more on $\mathrm{PhD}$ and Masters level rather than technical training which is needed more in the Kenyan SWT industry.

Site-specific assessments which are crucial to the installation of SWT are hardly conducted ( 8 out of 11 respondents) and available national resources such as the Solar and Wind Energy Resource Atlas are hardly consulted. Interaction with international actors, such as the Nordic Folkecenter in Denmark which has extensive experience in testing of SWT and has made valuable contribution to the diffusion of SWT in Denmark, was reported to be non-existent. A partnership between the Ministry of Energy (MOE) and the Danish Technical 
University (DTU) which is highly experienced in site-specific assessments for SWT installation was initiated in 2018 through the Kenya Miniwind Project. The project was terminated in late 2019 because the SWT market in Kenya and sub-Saharan Africa was established to be small.

\section{Function 3: knowledge diffusion through networks}

The only network available for SWT business firms is KEREA but the membership is dominated by solar PV companies, and therefore the discussion on SWT is rather limited. Study tours organised by KEREA to the European region were reported to offer little benefit for learning by Kenyan business firms who preferred to venture into the Asian markets which offered cheaper RE products such as solar PV. The diffusion of knowledge through fairs and exhibitions is similarly inhibited by the inherent focus of these events on solar PV. This was confirmed from the programmes of the fairs and exhibitions held during the data collection period, despite the research finding that these events constituted important modes of knowledge exchange. Knowledge exchange with established centres of excellence, such as the Nordic Folkecenter which has a good reputation of diffusing research findings from the testing of small wind turbines in the Nordic countries, was established to be limited (4 out of 11 interview respondents). The sharing of knowledge between business firms, financial institutions, tertiary institutions, and government and R\&D agencies was reported by survey respondents (6 out of 11) to be limited due to the fear of disclosing business secrets. This constrains learning experiences beneficial for developing new designs through modifications for improved performance and therefore it inhibits the diffusion of innovations (Lundvall, 2017). Available information on local markets for solar/wind hybrids was indicated to be out of date with the most recent developments (15 out of 24 interview respondents). This limits the ability of business firms to assess the actual demand for SWT technology even in areas of high potential such as the northern parts of the country.

\section{Function 4: guidance of the search/articulation of demand}

The Sustainable Energy for All Action Agenda recommends the development of clear goals and targets that could facilitate electricity access through the use of decentralised supply options, such as small wind in areas where the wind speeds permit off-grid integration, but so far, plans, such as the rural electrification master plan, do not clearly portray the demand from such sources (MOEP, 2016). Among the planned projects are the 26 mini-grids being developed by Rural Electrification and Renewable Energy Corporation (REREC), formerly known as Rural Electrification Agency (REA), and 13 planned mini-grids by the private sector - as outlined by the government in early 2019 (Kenya Miniwind, 2018), none of which incorporate small wind. Further, the experience of Safaricom Company which depends on small wind turbine technology 
to power the communication sector is yet to elicit lessons on the benefits of small wind to low-income households and business sectors (3 out of 11 respondents). China and India are documented to represent developing economies that have leapfrogged the diffusion of SWT to supply electricity in remote regions (Lewis, 2011). However, Kenya, which is documented to have good wind speeds in some regions, is yet to be listed as successfully diffusing small wind. Inadequate government support for decentralised electrification, and in particular mini-grids, limits their contribution to electricity access (Pueyo, 2015).

\section{Function 5: market formation}

The Kenyan Government's actions in the RE sphere demonstrate an inherent bias to solar PV installation in schools and health centres, while large wind systems such as Lake Turkana and Kipeto Wind projects are promoted for grid connection, a strategy interpreted as targeting foreign investment for large projects (Hansen et al., 2018) at the expense of SWT (6 out of 11 interview respondents). This is evident in the national electrification plans and donor programmes, the majority of which favour hybrid mini-grids largely based on solar PV and diesel and only a few of these incorporate SWT (Hansen et al., 2018). The energy sector operated without an official policy until 2004 but even then, for 13 years the policy was primarily focused on the development of geothermal, small hydropower, and solar PV. Later years have aroused interest in developing small hydropower which culminated in a small hydropower Atlas, but up to late 2019, government interest in SWT has been minimal. The incorporation of net metering among other provisions in the Government of Kenya (2019) Energy Act is expected to open up avenues for diversifying decentralised electricity generation. However, the extent to which these provisions will stimulate the diffusion of SWT remains unclear given that the obstacles to local manufacturing of SWT still remain pertinent in the form of taxation of batteries which are part and parcel of SWT systems; absence of Value Added Tax (VAT) waiver on imported SWT turbines; and the insufficiently developed supply chain for SWT countrywide (Berges, 2007).

\section{Function 6: resources mobilisation}

According to data collected from case studies, more financing is available for solar PV development than SWT (Pueyo, 2015). For example, the development support available from Power Africa (RES4Africa Foundation, 2015) is focused on solar PV and none of the projects supported includes SWT. The availability of angel investment as well as government financing for developing SWT projects is still lacking in Kenya, according to two consultants, six business firms and five other actors. The Danish funded Kenya Miniwind was a four year project aimed at supporting SWT development at a cost of 10.7 Million Danish Kroner ${ }^{1}$ (Rambøll, 2017). 
The key objective of this project was to demonstrate that a partially locally produced and operated wind turbine could contribute to affordable and reliable electricity in Kenya through mini-grids, stimulating employment and growth, and creating a market for smart mini-grids in Kenya and the region. The economic sustainability of the project was based on studies by Vestas which indicated the possibility of developing a new $\mathrm{kW}$ wind turbine which could compete with solar PV mini-grids in areas established to have medium inland wind regimes. This project was terminated in 2019 because of the small size of the SWT market in Kenya and sub-Saharan Africa.

Generally, financing institutions in Kenya have been reluctant to bear the risks associated with the promotion of SWT technology which is dominated by small companies of one to five employees. The lack of financing opportunities limits the growth potential of small firms and their ability to develop viable business models, hence reduces the dream of leapfrogging SWT technology within the sub-Saharan region to a mirage. The cost of installing SWT can be reduced by relying on local skills for constructing the tower whose price is about onethird of the total system cost and sourcing the electronic components from the Kenyan market since these are similar to those used for solar PV (interview with a manufacturer of SWT in Denmark). This implies the availability of a latent potential to reduce the cost of importing technology from foreign manufacturers since importation would be limited to highly specialised components, such as the blades, which require a certain level of expertise for the manufacturing process.

\section{Function 7: creation of legitimacy and counteracting resistance to change}

Some formal lobbying for the diffusion of SWT is confined to research groups such as the Innovation and Renewable Electrification in Kenya (IREK) project (www.irekproject.net) which successfully presented to the Kenyan Parliament a case on the need to incorporate the development of local capabilities for RE electrification in the Energy Act (Government of Kenya, 2019). The IREK project is coordinated by the African Centre for Technology Studies (ACTS) and hence reflects the role of Non-Governmental Organisations (NGOs) in creating legitimacy. Others include Delft University in the Netherlands which has conducted extensive research on SWT in Kenya using the multi-level perspective and strategic niche management approach (Kamp and Vanheule, 2015); and Jomo Kenyatta University of Agriculture and Technology which had previous collaboration on a capacity-building initiative with the Japanese International Cooperation Agency and later developed low cost prototypes (Haroub, Ochieng, and Kamau, 2015; Kasera, Ochieng, and Kinyua, 2015). Other groups such as the wind empowerment group through collaboration with the Low Carbon Energy for Development Network, Loughborough University, United Kingdom (Leary et al., 2018) have shown some interest in SWT development in Kenya, but their operations have been more at the international level. The United Nations 
Development Programme initiated discussions with Ministry of Energy (MOE) to collaborate in developing the market for SWT in Kenya in 2015, but the initiative failed to materialise due to unavailability of financing, according to sources from MOE. The Kenyan Government's collaboration with the Danish government in the Kenya Miniwind Project and Vestas was expected to open up avenues for the diffusion of SWT, but with its termination, this is unlikely to be achieved. The two local manufacturers of SWT have unsuccessfully lobbied for recognition of SWT in government circles but so far they have not realised any significant policy support

\section{Evaluation of the fulfilment of the seven functions of the SWT TIS in Kenya}

This section presents an evaluation of the fulfilment of each of the seven functions of the SWT TIS in Kenya. The explanation for the evaluation of each function is presented in Table 5.3 (later in this chapter) which was generated by examining how each indicator contributes to the fulfilment of each function with respect to the diffusion of SWT.

According to Hekkert et al. (2011), understanding the performance of the TIS functions requires recognition of the elements of the functions that are facilitatory (inducing) and those that present obstacles to the fulfilment of the system functions (blocking). The assessment of the contribution of each function to the performance of the TIS is only feasible after constructing the narrative, through assignment of +1 for a positive contribution and -1 for a negative contribution (Table 5.3). The resulting sum of the data points thus gives insights into the overall effects of each function and whether they can be rated as either positive (inducing) or negative (blocking) (Hekkert and Negro, 2009). Based on this approach, the inducing or blocking effect for each function is discussed below.

Function 1: entrepreneurial activities is largely limited because of the primary focus of SWT firms on solar PV and the lower number of firms compared to solar PV, low sales of SWT, low levels of local manufacturing, limited use of external expertise in operations, and limited access to financing (Table 5.3). The cumulative effect of this function is -4 .

Function 2: knowledge development is largely unfulfilled because of limited availability of up to date knowledge, sector doubts about the adequacy of the training curriculum at tertiary level, limited level of experimentation, absence of venturing into hotspots, absence of reverse engineering and commercialisation, unavailability of test facilities, and limited linkage between business firms and public research. Tertiary learning agencies exist but only one is active in SWT, and available local manufacturers have attempted to commercialise with limited success. The cumulative effect of this function is -7 .

Function 3: knowledge diffusion through networks is only partially fulfilled by the availability of networks which mostly focus on solar PV, limited levels of networking with local and foreign actors, and low interactions and 
TABLE 5.3 The established performance of the SWT Innovation System in Kenya (using modified indicators $(+=$ inducing, $-=$ blocking)

\begin{tabular}{|c|c|c|c|}
\hline Functions & $\begin{array}{l}\text { Indicators (as modified in the } \\
\text { methodology) }\end{array}$ & $\begin{array}{l}\text { Description of the indicators by the } \\
\text { study respondents (qualitative and } \\
\text { quantitative) }\end{array}$ & $+/-$ \\
\hline \multirow[t]{6}{*}{$\begin{array}{l}1 \text { Entrepreneurial } \\
\text { activities }\end{array}$} & Activities focus & $\begin{array}{l}\text { SWT firms focus on solar PV } \\
\text { which has about } 30-40 \\
\text { importers }\end{array}$ & -1 \\
\hline & Number of firms in the TIS & 20 SWT firms & +1 \\
\hline & Sales of SWT & $\begin{array}{l}\text { A total of one to five units } \\
\text { over four years }\end{array}$ & -1 \\
\hline & Local manufacturing & Two local manufacturers & -1 \\
\hline & Use of external expertise & Negligible & -1 \\
\hline & Access to financing & Limited & -1 \\
\hline \multirow[t]{11}{*}{$\begin{array}{l}2 \text { Knowledge } \\
\text { development }\end{array}$} & $\begin{array}{l}\text { Availability of up to date } \\
\text { knowledge }\end{array}$ & Limited & -1 \\
\hline & $\begin{array}{l}\text { Intensity of higher level } \\
\text { education for skills } \\
\text { development }\end{array}$ & $\begin{array}{l}\text { One tertiary learning } \\
\text { institution active }\end{array}$ & +1 \\
\hline & $\begin{array}{l}\text { Adequacy of the training } \\
\text { curriculum }\end{array}$ & $\begin{array}{l}\text { Outdated ( } 3 \text { out of } \\
11 \text { respondents) }\end{array}$ & -1 \\
\hline & $\begin{array}{l}\text { Evidence base (learning } \\
\text { by doing/using) } \\
\text { (commercialisation) }\end{array}$ & $\begin{array}{l}\text { Only two manufacturers } \\
\text { engaged in learning by } \\
\text { doing and in commercial } \\
\text { production }\end{array}$ & +1 \\
\hline & Level of experimentation & $\begin{array}{l}\text { A } 2018 \text { project shelved, earlier } \\
\text { experimentation did not } \\
\text { result in diffusion }\end{array}$ & -1 \\
\hline & Venturing into wind hotspots & $\begin{array}{l}\text { Limited ( } 3 \text { out of } \\
11 \text { respondents) }\end{array}$ & -1 \\
\hline & Reverse engineering & $\begin{array}{l}\text { Two prototypes not } \\
\text { commercialised }\end{array}$ & -1 \\
\hline & $\begin{array}{l}\text { Conducting feasibility } \\
\text { assessments }\end{array}$ & Non existent & -1 \\
\hline & $\begin{array}{l}\text { Availability of test facilities } \\
\text { for SWT }\end{array}$ & Zero reported & -1 \\
\hline & $\begin{array}{l}\text { Linkages with public } \\
\text { research organisations }\end{array}$ & Reported as low & -1 \\
\hline & $\begin{array}{c}\text { Local worker skills } \\
\text { development }\end{array}$ & $\begin{array}{l}\text { Limited enhancement of skills } \\
\text { of available engineers }\end{array}$ & -1 \\
\hline \multirow{5}{*}{$\begin{array}{l}3 \text { Knowledge } \\
\text { diffusion } \\
\text { through } \\
\text { networks }\end{array}$} & Availability of networks & One functional network & +1 \\
\hline & Focus of networks & Solar PV & -1 \\
\hline & $\begin{array}{l}\text { Networking capabilities with } \\
\text { local and foreign actors }\end{array}$ & Reported to be low & -1 \\
\hline & $\begin{array}{l}\text { Interactions and knowledge } \\
\text { sharing }\end{array}$ & 4 out of 11 respondents & -1 \\
\hline & $\begin{array}{l}\text { Knowledge of the Kenyan } \\
\text { market }\end{array}$ & Two local manufacturers & +1 \\
\hline
\end{tabular}


TABLE 5.3 (Continued)

\begin{tabular}{|c|c|c|c|}
\hline Functions & $\begin{array}{l}\text { Indicators (as modified in the } \\
\text { methodology) }\end{array}$ & $\begin{array}{l}\text { Description of the indicators by the } \\
\text { study respondents (qualitative and } \\
\text { quantitative) }\end{array}$ & $+/-$ \\
\hline & $\begin{array}{l}\text { Integration of new } \\
\text { knowledge }\end{array}$ & $\begin{array}{l}\text { Reported as low by business } \\
\text { firms }\end{array}$ & -1 \\
\hline & $\begin{array}{l}\text { Awareness on benefits of } \\
\text { SWT }\end{array}$ & $\begin{array}{l}\text { Reported as low by business } \\
\text { firms }\end{array}$ & -1 \\
\hline & $\begin{array}{l}\text { Public awareness of } \\
\text { technology and awareness } \\
\text { creation }\end{array}$ & $\begin{array}{l}\text { Reported as low by business } \\
\text { firms }\end{array}$ & -1 \\
\hline & $\begin{array}{l}\text { No. of systems and } \\
\text { demonstrations installed }\end{array}$ & About 500 systems installed & +1 \\
\hline \multirow[t]{5}{*}{$\begin{array}{l}4 \text { Guidance of } \\
\text { the search/ } \\
\text { articulation of } \\
\text { demand }\end{array}$} & $\begin{array}{l}\text { Government long-term goals } \\
\text { for SWT }\end{array}$ & $\begin{array}{l}\text { Limited number of SWT } \\
\text { projects identified in energy } \\
\text { sector plans and budgets } \\
\text { compared to solar PV }\end{array}$ & -1 \\
\hline & $\begin{array}{l}\text { Industry long-term goals for } \\
\text { SWT }\end{array}$ & $\begin{array}{l}\text { None reported or found in } \\
\text { literature }\end{array}$ & -1 \\
\hline & $\begin{array}{l}\text { Incorporation of SWT in } \\
\text { ongoing projects }\end{array}$ & $\begin{array}{l}0 \text { out of } 39 \text { ongoing mini-grid } \\
\text { projects by government and } \\
\text { partners }\end{array}$ & -1 \\
\hline & $\begin{array}{l}\text { Utilisation of lessons } \\
\text { from successful and } \\
\text { unsuccessful projects }\end{array}$ & 3 out of 11 respondents & -1 \\
\hline & $\begin{array}{l}\text { Coverage of positive SWT } \\
\text { developments in Kenya in } \\
\text { professional journals }\end{array}$ & $\begin{array}{l}\text { None reported or found in } \\
\text { literature }\end{array}$ & -1 \\
\hline \multirow[t]{8}{*}{$\begin{array}{l}5 \text { Market } \\
\text { formation }\end{array}$} & Development focus & $\begin{array}{l}6 \text { out of } 11 \text { respondents } \\
\text { indicate strong government } \\
\text { focus on solar PV and wind }\end{array}$ & -1 \\
\hline & $\begin{array}{l}\text { Support for developing SWT } \\
\text { mini-grids }\end{array}$ & Regulatory framework absent & -1 \\
\hline & Supply chain development & Not evident from interviews & -1 \\
\hline & Availability of leadership & $\begin{array}{l}\text { Unfavourable government } \\
\text { leadership }\end{array}$ & -1 \\
\hline & Institutional structure & $\begin{array}{l}\text { None established from } \\
\text { literature }\end{array}$ & -1 \\
\hline & $\begin{array}{l}\text { Policy planning, } \\
\text { implementation }\end{array}$ & $\begin{array}{l}\text { Focused on solar PV and large } \\
\text { wind }\end{array}$ & -1 \\
\hline & $\begin{array}{l}\text { Availability and adequacy } \\
\text { of regulations, standards, } \\
\text { incentives, and local } \\
\text { content }\end{array}$ & None identified in literature & -1 \\
\hline & $\begin{array}{l}\text { Clarity of policy signals on } \\
\text { SWT }\end{array}$ & Unclear & -1 \\
\hline
\end{tabular}


TABLE 5.3 (Continued)

\begin{tabular}{|c|c|c|c|}
\hline Functions & $\begin{array}{l}\text { Indicators (as modified in the } \\
\text { methodology) }\end{array}$ & $\begin{array}{l}\text { Description of the indicators by the } \\
\text { study respondents (qualitative and } \\
\text { quantitative) }\end{array}$ & $+/-$ \\
\hline \multirow[t]{5}{*}{$\begin{array}{l}6 \text { Resources } \\
\text { mobilisation }\end{array}$} & $\begin{array}{l}\text { Government investments/ } \\
\text { priorities }\end{array}$ & $\begin{array}{l}\text { Strong bias to solar PV and } \\
\text { large wind }\end{array}$ & -1 \\
\hline & Budgetary support for SWT & None identified & -1 \\
\hline & $\begin{array}{l}\text { Foreign investments/ } \\
\text { technical assistance }\end{array}$ & Very limited & -1 \\
\hline & $\begin{array}{l}\text { Risk taking by financing } \\
\text { institutions }\end{array}$ & $\begin{array}{l}\text { Highly reluctant to take risks } \\
\text { ( } 6 \text { out of } 12 \text { respondents) }\end{array}$ & -1 \\
\hline & $\begin{array}{l}\text { Availability of business } \\
\text { models }\end{array}$ & $\begin{array}{l}\text { Not available when compared } \\
\text { with solar PV }\end{array}$ & -1 \\
\hline \multirow{4}{*}{$\begin{array}{l}7 \text { Creation of } \\
\text { legitimacy/ } \\
\text { counteract } \\
\text { resistance to } \\
\text { change }\end{array}$} & Availability of lobby groups & $\begin{array}{l}\text { Research groups e.g., IREK } \\
\text { and Delft University, one } \\
\text { tertiary learning institution }\end{array}$ & +1 \\
\hline & Lobbying through formal & Wind empowerment group & +1 \\
\hline & networks & $\begin{array}{l}\text { United Nations Development } \\
\text { Programme (stalled } \\
\text { project), Kenya Miniwind } \\
\text { Project shelved }\end{array}$ & \\
\hline & $\begin{array}{l}\text { Lobbying via informal } \\
\text { networks }\end{array}$ & $\begin{array}{l}\text { Two local manufacturers have } \\
\text { lobbied but with no success }\end{array}$ & -1 \\
\hline
\end{tabular}

Source: author; based on TIS functions by Hekkert et al. (2007).

knowledge sharing. The level of integration of new knowledge in firms and awareness of the benefits of SWT is also low. The low awareness is compounded by limited numbers of demonstrations. The local manufacturers have a good knowledge of the market unlike the distributor firms whose understanding of the market is limited. The cumulative effect of this function is -3 .

Function 4: guidance of the search is weakened by the absence of longterm goals for SWT in both industry and government, non-incorporation of SWT in ongoing mini-grids, limited utilisation of lessons from successful and unsuccessful projects, and no coverage of positive SWT developments in Kenya in professional journals. The cumulative effect of this function is -5 .

Function 5: market formation is constrained by the development and policy focus by the leadership in the energy sector on solar PV and large wind, absence of a regulatory framework for mini-grids and institutional structure for SWT development, inadequacy of the SWT supply chain, and lack of incentives and standards for SWT. The cumulative effect of this function is -8 .

Function 6: resources mobilisation is blocked by low prioritisation of SWT in government investments and budgetary allocation, limited availability of foreign investments in SWT, low risk taking by available government financing institutions, and limited availability of business models compared to solar PV. The cumulative effect of this function is -5 . 
Function 7: creation of legitimacy is weakly fulfilled by the availability of lobby groups such as the Innovation and Renewable Electrification in Kenya research group among other formal organisations. Informal organisations have tried to lobby unsuccessfully. The cumulative effect of this function is +1 .

The phase of development of the SWT TIS was determined by asking specific diagnostic questions relating to each phase. The pre-development phase of the TIS is characterised by the availability of a working prototype, the development phase by commercial application, the take-off phase by fast market growth, and the acceleration phase by market saturation (Hekkert et al., 2011). The preceding assessment of the performance of the SWT TIS in Kenya indicates that it is still in the pre-development phase because a working prototype exists but efforts to commercialise are limited. All the conditions in the remaining three phases are yet to be fulfilled.

\section{Conclusion}

On the existence of an SWT TIS in Kenya, it is concluded based on the mapping of actors, institutions, and networks that most of the actors required to constitute a TIS are present, except demand which was not analysed in this study. The research question on how well the Kenyan SWT functions are fulfilled was answered by analysing the TIS functions. Based on the scale defined in the methodology section, the four functions with the strongest blocking effect are market formation, knowledge development, resources mobilisation, and guidance of the search. The functions of entrepreneurial activities and knowledge diffusion are weakly blocking, while the function of creation of legitimacy is weakly inducing. The identified weaknesses in the Kenyan SWT TIS therefore render it unfavourable for the diffusion of SWT. This finding corroborates the observation that the SWT TIS is still in the pre-development phase despite the long history of SWT in Kenya. This finding is supported in literature by Negro, Alkemade, and Hekkert (2012) who observed that diffusion of RE technologies is sometimes a slow and tedious process.

Available literature suggests that focusing policy intervention on remedying the poor functionality of the TIS functions could strengthen the inducing mechanisms and minimise the effect of the blocking mechanisms (Hekkert et al., 2011). Key areas of intervention in view of the small market revolve around enhancing government support for SWT development by conducting site-specific assessments in potential areas, enhanced $\mathrm{R} \& \mathrm{D}$, support for the integration of SWT in hybrid mini-grids (Nandi and Ghosh, 2010), setting specific goals for SWT development, allocation of government and development partner support for SWT development, and support for local manufacturing and market development.

The number of empirical studies that apply the TIS framework to the developing country context in published literature is established to be growing steadily. This could be a sign that the TIS framework is increasingly found beneficial 
for analysing the performance of technological innovation systems in different sectors of developing economies. Using the TIS framework to study the SWT innovation system in Kenya is thus considered a contribution to the growing interest in the use of this framework in the developing country context with specific reference to the African region. Using this framework in the developing country context entails adjustment of the indicators to the specific national and sectoral context under study, as well as weighting of the research findings using the same indicators applied to empirical studies. This facilitates objective interpretation and enhanced reliability of the recommendations.

The limitations faced in studying the diffusion of SWT using the TIS framework relate to the static nature of the analysis which makes it difficult to determine whether the SWT TIS is advancing or declining. Furthermore, different weighting mechanisms could produce variations in the results in which case the application to other contexts could be limited. Additional empirical studies that enhance the assessment of indicators for specific technologies are thus recommended. This study points towards the possibility of implementing solar PV/SWT hybrids (Carmago et al., 2019), provided site-specific assessments are conducted in specific areas. Accounts of the Kenya Miniwind Project (2018), however, indicate the Kenyan market for SWT to be small, a finding which led to termination of the project. Research studies, such as Johannesen (2019) on the integration of small wind turbines in mini-grids in Kenya, are considered important contributions towards attaining the inflexion point in the diffusion curve for SWT from the pre-development to the development phase. The blocking and inducing mechanisms identified in this chapter, if addressed, could lead to this transition.

\section{Acknowledgements}

The research on which this chapter is based was supported by the Danish Ministry of Foreign Affairs, Grant: DFC 14-09AAU. All input by the editorial team towards finalising this chapter is greatly appreciated. This chapter is based on an upcoming $\mathrm{PhD}$ research by the author and a journal paper (Wandera, 2020).

\section{Note}

11 Danish Kroner $=$ United States Dollar 0.15 or Kenya Shillings 15.27 at time of writing.

\section{References}

Aguinis, H., Chaddad, F.R., Harrigan, K.R., Hoon, C. et al. (2011) 'Research methodology in strategy and management', The International Journal of Health Planning and Management, 26(4), pp. 488-490, https://onlinelibrary.wiley.com/doi/full/10. 1002/hpm.1118 
van Alphen, K., Hekkert, M.P. and van Sark, W.G.J.H.M. (2008) 'Renewable energy technologies in the Maldives-realising the potential', Renewable and Sustainable Energy Reviews, 12(1), pp. 162-180. https://doi.org/10.1016/j.rser.2006.07.006

Ashok, S. (2007) 'Optimised model for community-based hybrid energy system', Renewable Energy, 32(7), pp. 1155-1164. https://doi.org/10.1016/j.renene.2006.04.008

Bergek, A., Hekkert, M., Jacobsson, S., Markard, J., Sandén, B. and Truffer, B. (2015) 'Technological innovation systems in contexts: Conceptualising contextual structures and interaction dynamics', Environmental Innovation and Societal Transitions, 16, pp. 5164. https://doi.org/10.1016/j.eist.2015.07.003

Berges, B. (2007) Development of Small Wind Turbines. Lyngby, Denmark: Technical University of Denmark, pp. 66-69.

Bruton, G.D., Ahlstrom, D. and Obloj, K. (2008) 'Entrepreneurship in emerging economies: the research go in the future', Entrepreneurship Theory and Practice, 32(January), pp. 1-14. https://doi.org/10.1111/j.1540-6520.2007.00213.x

Carmago, L.R., Gruber, K., Nitsch, F. and Dorner, W. (2019) 'Hybrid renewable energy systems to supply electricity self-sufficient residential buildings in central Europe', Energy Procedia, 158(2019), pp. 321-326. https://10.1016/j.egypro.2019.01.096

Eales, A. (2014) 'Locally manufactured small wind turbines in Ethiopia: Is the levelised cost of energy competitive with alternatives for rural electrification, and if so, where?', p. 149. Available at: https://www.academia.edu/7865944/ (Accessed: 20/06/2018).

Edquist, C. (2001) 'The systems of innovation approach and innovation policy: An account of the state of the art' in DRUID Conference, Aalborg, (December), pp. 1215. Available at: https://www.researchgate.net/publication/228823918 (Accessed: 20/06/2018).

Edsand, H.E. (2016) 'Technological innovation systems and the wider context: A framework for developing countries', UNU-MERIT Working Papers, 17, p. 38. Available at: https://www.eadi.org/publications/publication_55276/ (Accessed: 25/06/2018).

Edsand, H.E. (2017) 'Identifying barriers to wind energy diffusion in Colombia: A function analysis of the technological innovation system and the wider context', Technology in Society, 49, pp. 1-15. https://doi.org/10.1016/j.techsoc.2017.01.002

Fleck, B. and Huot, M. (2009) 'Comparative life-cycle assessment of a small wind turbine for residential off-grid use', Renewable Energy, 34(12), pp. 2688-2696. https://doi.org /10.1016/j.renene.2009.06.016

Foster, R. (2011) 'Energy in developing countries', Trade, Investment, and Sustainable Development, 11(3), pp. 27-28. Available at: https://digitalcommons.wcl.american . edu/cgi/viewcontent.cgi?article $=1487 \&$ context $=$ sdlp (Accessed: 29/06/2018).

Furtado, A.T. and Perrot, R. (2015) 'Innovation dynamics of the wind energy industry in South Africa and Brazil: Technological and institutional lock-ins', Innovation and Development, 5(2). https://doi.org/10.1080/2157930X.2015.1057978

Government of Kenya (2019) 'The energy act no 1 of 2019', Kenya Gazette Supplement Acts, 2019, 29(29). Available at: https://www.epra.go.ke/download/the-energy-act -2019/ (Accessed: 01/12/2019).

Hansen, U.E., Gregersen, C., Lema, R., Samoita, D. and Wandera, F. (2018) 'Technological shape and size: A disaggregated perspective on sectoral innovation systems in renewable electrification pathways', Energy Research and Social Science, 42, pp. 13-22. https://doi.org/10.1016/j.erss.2018.02.012

Haroub, H.A., Ochieng, F.X. and Kamau, J.N. (2015) 'Development of a low cost rotor blade for a H: Darrieus wind turbine', 2(3), pp. 92-99. Available at: https://pdfs .semanticscholar.org/0341/1a1c7e31c2b7bbb97661a3c31ffc3cc697d5.pdf (Accessed: 10/03/2019). 
Hekkert, M.P. and Negro, S.O. (2009) 'Functions of innovation systems as a framework to understand sustainable technological change: Empirical evidence for earlier claims', Technological Forecasting and Social Change, 76(4), pp. 584-594. https://doi.org/10.1016 /j.techfore.2008.04.013

Hekkert, M.P., Suurs, R.A.A., Negro, S., Kuhlmann, S. and Smits, R.E.H.M. (2007) 'Functions of innovation systems: A new approach for analysing technological change', Technological Forecasting and Social Change, 74(4), pp. 413-432. https://doi.org/10.1016 /j.techfore.2006.03.002

Hekkert, M.P., Negro, S., Heimeriks, G, Harmsen, R.O. and Jong, S.D. (2011) 'Technological innovation system analysis: A manual for analysts', Utrecht University. Available at: https://www.semanticscholar.org/paper/Technological-Innovation-Sy stem-Analysis-A-manual-Hekkert-Negro/68e1abecbbe0da073c7e63d95dbb750f5 d910024 (Accessed: 20/11/2018).

Jacobsson, S. and Johnson, S. (2000) 'The diffusion of renewable energy technology: An analytical framework and key issues for research', Energy Policy, 28(9), pp. 625-640. http://dx.doi.org/10.1016/S0301-4215(00)00041-0

Jensen, M.B., Johnson, B., Lorenz, E. and Lundvall, B.Å. (2007) 'Forms of knowledge and modes of innovation', Research Policy, 36(5), pp. 680-693. https://doi.org/10.1016 /j.respol.2007.01.006

Johannsen, R.M. (2019) 'Hybrid PV and wind mini-grids in Kenya: Barriers and potential for diffusion Hybrid PV and wind mini-grids in Kenya: Barriers', 4. Available at: https://www.irekproject.net/portfolio/wp4/ (Accessed: 11/02/2020).

Kamp, L.M. and Vanheule, L.F.I. (2015) 'Review of the small wind turbine sector in Kenya: Status and bottlenecks for growth', Renewable and Sustainable Energy Reviews. https://doi.org/10.1016/j.rser.2015.04.082

Kasera, A.A., Ochieng, F.X. and Kinyua, R. (2015) 'Design and testing of a low cost and higher efficient savonius wind turbine's rotor blade for low wind speed applications', Open Access Journal of Sustainable Research in Engineering, 2(1), pp. 23-35. Available at: http://ir.jkuat.ac.ke/handle/123456789/2246 (Accessed: 20/03/2019).

Kebede, K.Y. and Mitsufuji, T. (2016) 'Technological innovation system building for diffusion of renewable energy technology: A case of solar PV systems in Ethiopia', 114(2017), pp. 242-253. https://doi.org/10.1016/j.techfore.2016.08.018

Kenya Miniwind (2018) Market for the Integration of Smaller Wind Turbines in Mini-grids in Kenya. Available at: https://backend.orbit.dtu.dk/ws/files/158704528/Kenya_mini _grid_market_study_FINAL.pdf (Accessed: 05/05/2019).

Kingiri, A.N. and Fu, X. (2019) 'Understanding the diffusion and adoption of digital finance innovation in emerging economies: M-Pesa money mobile transfer service in Kenya', Innovation and Development, 10(1), pp. 67-87. https://doi.org/10.1080/215793 0x.2019.1570695

Kuratko, D.F. (2010) 'Corporate entrepreneurship: An introduction and research review' in Audretch D.B. and Zoltan, J.A. (eds.) Handbook of Entrepreneurship Research. Available at: https://link.springer.com/book/10.1007/978-1-4419-1191-9 (Accessed: 13/01/2020).

Leary, J., To, L.S. and Alsop A. (2018) 'Is there still a role for small wind in rural electrification programmes?', LCEDN Briefing Paper 2, pp. 1-17. Available at: www .lcedn.com (Accessed: 13/01/2020).

Lewis, J.I. (2007) 'Technology acquisition and innovation in the developing world: Wind turbine development in China and India', Studies in Comparative International Development, 42(3-4), pp. 208-232. https://doi.org/10.1007/s12116-007-9012-6 
Lewis, J.I. (2011) 'Building a national wind turbine industry: Experiences from China, India and South Korea', International Journal of Technology and Globalisation, 5(3/4), p. 281. https://doi.org/10.1504/IJTG.2011.039768

Lewis, J. and Wiser, R. (2005) 'Fostering a renewable energy technology industry: An international comparison of wind industry policy support mechanisms', eScholarship Publishing. Available at: https://escholarship.org/uc/item/6cf1r3z5 (Accessed: 08/03/2018).

Lundvall, B.-A. (2017) The Learning Economy and the Economics of Hope. London and New York: Anthem Press. https://doi.org/10.26530/oapen_626406

Markard, J. and Truffer, B. (2008) 'Actor-oriented analysis of innovation systems: Exploring micro-meso level linkages in the case of stationary fuel cells', Technology Analysis and Strategic Management, 20(4), pp. 443-464. https://doi.org/10.1080/0 9537320802141429

Ministry of Energy and Petroleum (MOEP) (2016) Sustainable Energy for All Action Agenda. Available at: https://www.renewableenergy.go.ke/asset_uplds/files/SE4All \%20AA\%20Report\%20Final\%2010\%20March\%202016.pdf (Accessed: 10/11/2018).

Nandi, S.K., and Ghosh, H. R., (2010). 'Prospect of windePV-battery hybrid power system as an alternative to grid extension in Bangladesh', Energy, 35(2010), pp. 30403047. https://doi.org/10.1016/j.energy.2010.03.044

Negro, S.O., Alkemade, F. and Hekkert, M.P. (2012) 'Why does renewable energy diffuse so slowly? A review of innovation system problems', Renewable and Sustainable Energy Reviews, 16(2012), pp. 3836- 3846. https://doi.org/10.1016/j.rser.2012.03.043

Nema, P., Nema, R. K., and Rangnekar, S. (2008) 'A current and future state of art development of hybrid energy system using wind and PV-solar: A review', Renewable and Sustainable Energy Reviews, 13(2009), pp. 2096-2103. https://doi:10.1016/j. rser.2008.10.006

Organisation for Economic Co-operation and Development (OECD) (2008) 'National innovation systems', International Journal of Entrepreneurship and Innovation Management, 8(1), p. 74. https://doi.org/10.1504/IJEIM.2008.018615

Pitteloud, J.-D. and Gsänger, S. (2017) 2017 Small Wind World Report Summary. Available at: https://issuu.com/wwindea/docs/swwr2017-summary (Accessed: 10/01/2019).

Pueyo, A. (2015) 'Pro-poor access to green electricity in Kenya', Pro-Poor Electricity Provision, 135. Institute of Development Studies, pp. 29-31.

Rambøll, B. (2017) Supporting Sustainable Mini-grid Development and Local Production of Wind Turbines Using the Case of Kenya. Available at: https://orbit.dtu.dk/en/projec ts/supporting-sustainable-mini-grid-development-and-local-production (Accessed: 15/08/2018).

RES4Africa Foundation (2015). Available at: https://www.res4africa.org/wp-content/ uploads/2016/05/Power-Africa-Fact-Sheet.pdf (Accessed: 11/06/2018).

al-Saleh, Y.M. (2011) 'LR1-An empirical insight into the functionality of emerging sustainable innovation systems: the case of renewable energy in oil-rich Saudi Arabia', International Journal of Transitions and Innovation Systems, 1(3), p. 302. https://doi.org /10.1504/IJTIS.2011.042662

Tigabu, A., Berkhout, F. and Beukering, P. (2014) 'Technology innovation systems and technology diffusion: Adoption of bio- digestion in an emerging innovation system in Rwanda', Technological Forecasting and Social Change, 90(January 2016), pp. 318-330. https://doi.org/10.1016/j.techfore.2013.10.011

Wandera, F.H. (2020) 'The innovation system for diffusion of small wind in Kenya: Strong, weak or absent? A technological innovation system analysis', African Journal of Science, Technology, Innovation and Development [Online]. https://doi.org/10.1080/2 0421338.2020.1771979 